\title{
Self-regulatory investments among private actors in the era of regulatory capitalism: the licensing of Swedish finance and securities industry employees
}

\author{
Oskar Engdahl ${ }^{1}$ iD
}

Published online: 6 January 2018

(C) The Author(s) 2018. This article is an open access publication

\begin{abstract}
This article analyses the growth of the Swedish finance and securities industry's employee licensing programme to advance our understanding of the growth, conditions, and function of various forms of self-regulation in the era of regulatory capitalism. It examines how the situations that are significant for private actors' initiation and implementation of self-regulation are connected with the development of a particular form of self-regulation. The article argues that the licensing programme in question is an example of self-regulation characterized by impersonal trust, identity assurance, and integrity. This type of self-regulation is related to the conditions that characterized the finance and securities industry before and at the time of the initiative and its implementation, in particular, economic confidence, normalization and expansion, and increasing complexity and heterogeneity. The article is based mainly on document analysis and market statistics supplemented with interviews.
\end{abstract}

In recent years, several influential studies have demonstrated that the contemporary capitalist market economy is characterized by a "regulation explosion" that has led researchers to argue that we now live in an era of "regulatory capitalism" [1-4]. This refers to a multifaceted process whereby government and private actors have made significant investments in regulatory strategies with the aim of promoting market transactions $[1,5,6]$. In the finance and securities industry, this development has manifested itself in a strong drive to normalize securities investments, promote a "mass investment culture", and - to quote the Swedish Financial Supervisory Authority (Finansinspektionen; hereafter "the Authority") - create a "stock market for all" ([7]; see also [8, 9]). Private actors' own responsibility for shaping, implementing, and following up the regulation of their operations - i.e., self-regulation - has been key in

Oskar Engdahl

oskar.engdahl@socav.gu.se

1 Department of Sociology and Work Science, University of Gothenburg, Box 720, SE-405 30 Gothenburg, Sweden 
this process, and the development of internal corporate regulation and self-regulation has even been characterized as an "explosion" ([2]: 21; see also [4, 6, 10]).

The industry organization for the Swedish securities market, the Swedish Securities Dealers' Association (Svenska Fondhandlareföreningen; hereafter "the Association"), has been a prominent actor in this process. One conspicuous example is the Association's initiation of a programme to license Swedish finance and securities industry employees. This programme, though one of the first of its kind in the world, is not unique. During the twenty-first century, self-regulated licensing programmes for employees have developed and become a significant aspect of governance in an increasing number of securities markets. Even so, we lack studies of this kind of licensing programmes and answers to the question of why they have been realized and become an attractive form of regulation in the finance and securities industry during the era of regulatory capitalism. There is also a strong need for knowledge about the conditions that drive and shape attractive and sustainable types of self-regulation in the industry, particularly in times when self-regulation - due to financial crises and legitimation problems - is under criticism [11-13]. Consequently, this article analyses the Swedish licensing programme in order to contribute to our understanding about what motivates private actors to initiate and invest in self-regulation, and how the underlying challenges of the market constitute the kind of self-regulation emerging. The guiding research questions are therefore: What factors (i.e. situations in the market) seems to be significant for the motivation of private actors to initiate and implement a licensing programme, and how did those factors shape the form of self-regulation that emerged?

The Swedish case of licensing employees in the securities industry seem to be a particular good case because the same kind of program was launched but failed to get support in the beginning of the 90 s, but was re-launched, received immediate support and became successful in the late 90 s and forward. What makes the difference? The analysis of the program is centered on this issue and thus constitutes a case study with internal comparison [14]. In the following section, the article's primary argument and contribution are outlined in connection with certain key perspectives on regulatory capitalism and self-regulation will be dealt with. This will be followed by an introduction to the licensing programme and a description of the method and materials of the present study. The article's arguments and contribution will be developed in three sections analysing the growth and shaping of the licensing programme in relation to the transformation of the securities industry in recent decades.

\section{Regulatory capitalism and investment in self-regulation: a brief survey of the research}

In recent years the development of the global, capitalistic economy has been described in terms of" regulatory explosion" and "regulatory capitalism". The terms have been established to describe the era starting in the second half of the 1990s $[1,2,5]$. Influential studies have shown how "the rationale for the creation of regulatory agencies" has become stronger than" the rationale for privatization" during this period, resulting in a strong development of the number of regulations and regulatory organs ([2]: 19). Both governments and private actors have made investments in a regulatory capacity that aims to create more market actors and to ensure the functions of the 
markets; an ambition which has motivated rules and regulatory agencies for market transactions. Government actors have delegated and legitimated regulatory power created by other organisations. Government actors have exercised power" from a distance" rather than in detail. This has created and encouraged self-regulation and given the professional actors and experts an increased scope in their work when it comes to creating and maintaining regulations $[2,15,16]$. As a result of this a pluralistic regulatory landscape with diversity and combinations of different types of regulations and regulations agents have been created, i.e. state control, hybrid- and coregulation, as well as pure self-regulatory processes and private systems of control. Much of this regulation has entailed an increased involvement of private actors in setting the rules, in monitoring the rules and even enforcing new regulations, both in Sweden and internationally [17].

As I will argue in this article, the programme to license Swedish finance and securities industry employee is a significant example of the above described process. Although licensing employees have developed and become a significant aspect of governance in an increasing number of finance and securities markets during the twenty-first century studies on this type of licensing don't seem to exist. Some remarks about what generally can be the driving forces for private actors to invest in self regulation might therefore be necessary as a general analytical framework. Over the years, many studies have contributed to our knowledge of how self-regulation can be organized and of the advantages and disadvantages associated with various forms of self-regulation. ${ }^{1}$ As a result of these studies, there is now a rich conceptual apparatus and a theoretical tradition concerning how self-regulation can be defined and combined with other forms of regulation ([21]; for surveys, see [12, 22]). What leads private actors to invest in self-regulation and why government authorities encourage selfregulation among private actors and delegate regulatory power to self-regulatory authorities (SRAs) are questions that have also been well studied ([12]; see also [13]).

Less well studied, however, is the connection between situations of significance for the likelihood of private actors' investing in self-regulation and the occurrence of particular forms of self-regulation. One way to look at the connection is to construe self-regulation in terms of protection or defence that arises in situations in which the confidence of the business community in an operation has declined due to a financial crisis, crash, or scandal. It is conceivable that private actors then initiate self-regulation as a way to strengthen their operations' legitimacy, often in combination with a desire to prevent external actors (primarily government authorities) from introducing obligatory restrictions $[10,12,22]$. Legitimacy is prioritized in order to maintain status, selfdetermination, and control over the operation: self-regulation becomes a means of achieving this in that it can create an image of professional responsibility that creates "public credibility" [23]. Self-regulation can be understood here in terms of boundary work: it involves establishing boundaries with respect to the business environment and creating "legitimate paths of access to financial activities" ([19]: 459).

Damaged confidence as a driving force of private actors' initiation of self-regulation can also have an internal origin. Private actors can perceive each other as ignorant, consider that promises are not being kept, and suspect that counterparties are using dirty

\footnotetext{
${ }^{1}$ Self-regulation has a long history in banking and finance - probably as long as the industry itself. See further [18-20] for Sweden
} 
tricks or engaging in downright fraudulent business transactions. In such situations, actors can protect themselves by joining forces and using self-regulation to control an otherwise insecure market situation. Self-regulatory codes of conduct and SRAs can here be considered a type of protection organization or insurance company that either promotes fair play in a democratic spirit or evolves into a regulatory cartel in which actors try to obtain advantages at the expense of other actors - competitors, clients, or the public ([12]: 233f; [24]). Circumstances of this type touch upon situations in which market circumstances (i.e., the quality of goods, services, and actors) are difficult to identify, which is yet another circumstance that can motivate private actors to initiate self-regulation or to join an SRA [25]. When information is too uncertain or complex and transparency is low, common rules, guidelines, or standards increase the possibility of identifying other market actors and facilitate the selection of clients and business partners. Self-regulation can here be considered a way to "adopt policies which improve observable features of the activity and give the appearance of service unity" ([12]: 239). Self-regulatory elements in the form of membership requirements and screening processes can facilitate the information flow that market actors require to conduct business but also, naturally, serve a symbolic informational function or become a "case of symbolic politics" ([25]: 93).

It would seem that self-regulation is largely understood as a form of what can roughly be termed "access control" and is situated within the context of internal or external lack of trust and an operation's own protection requirements $[12,22,26]$. The fundamental notion seems to be that a certain lack of trust drives self-regulation in the form of access requirements that indicate who may legitimately perform an operation - a fundamentally exclusionary attitude. For financial markets, it has been argued, for example, that self-imposed restrictions on where trade may take place, with what financial instruments trade may be conducted, and who is entitled to trade on the market are examples of this [19]. Stringent requirements as to age, wealth, and payment capacity, permanent employment, national, ethnic, and religious affiliation, letters of recommendation, and certified suitability or "dependability" are among the requirements imposed on those seeking access to the trading floor; over the centuries, trading in securities has as a rule constituted an operation of "exclusive men's clubs" ([19]: 68).

However, it should also be possible to understand self-regulation as "identity assurance". This refers to a form of control there an actor must declare his or her identity and so centered around transparency. The essential thing is to facilitate the selection of business partners and make market transactions smoother. It is a form of control that can assume a more inclusive character rather than access to control because requirements which a priori excludes or limits some actors are never established. Focus is instead directed towards promoting transparency and the ability of market participants to make informed choices. In the analysis presented here, I argue that the growth of self-regulation in the Swedish securities industry in the form of a licensing programme is an example of when this driving force underlying private actors' investment in self-regulation has been primary. The analysis, in this case, is designed to help advance theory-building in the area, contribute to the generation of empirical evidence regarding it, and, it is hoped, spur ongoing research on the topic. 


\section{Employee licensing in the Swedish securities industry: a brief introduction}

The employee licensing programme in the Swedish securities industry was implemented by the Association and began operation in April 2001. Membership in the licensing programme is voluntary for banks, brokerages, and other companies active in the securities industry. Firms join the licensing scheme by affiliating themselves with SwedSec, a wholly owned subsidiary of the Association that manages the licensing scheme. SwedSec has a small staff and is structured around various task forces, committees, and boards whose members are recruited from the financial services sector, academia, and the legal system.

When affiliation with SwedSec has taken place, employees are required to obtain a license to gain access to certain positions and duties within the member firms. The requirements apply primarily to employees involved in providing professional advice, managing client assets, and producing investment analyses, and to employees responsible for these operations. To obtain a license, a person must obtain a passing grade on an examination and on annual knowledge updates. Essentially, these concern professional knowledge as to how the securities market and financial instruments work and how transactions involving them must be carried out, administered, and risk-assessed.

The licensing programme also includes the duty to report any suspected breach of regulations. Member companies commit to report a license holder to SwedSec if there are grounds to suspect that the license holder has acted in contravention of the rules that apply to that license ([27] and, especially [28]). All reported matters are investigated by a disciplinary committee, which presides over an arsenal of sanctions including reprimands, warnings, and license revocation. A revoked license implies that, for a period of up to three years, an employee must not undertake tasks that require a license in a member company. During the period from 2001 to autumn 2017, some 195 sanctions have been imposed, of which 65 were revoked licenses.

The licensing scheme was initiated as a form of industry-controlled self-regulation designed by the experts of the securities industry itself, and so it has remained. The Association has invested significant resources and considerable prestige in the project. All firms of any significance in the Swedish securities market affiliated themselves with the scheme from the start. In the years that followed, the licensing programme has been expanded and become a significant aspect of Swedish securities market governance. As of autumn of 2017, the scheme covers more than 180 firms and 22,600 active license holders.

\section{Data and methods}

The present study is based primarily on documents from the Swedish Securities Dealers' Association ("the Association") which created the licensing programme; the affiliate to the Association (SwedSec) that manage the licensing programme; the Swedish Financial Supervisory Authority ("the Authority"); and The Swedish Stock Exchange ("the Exchange"). Mainly it is documents document in the form of printed policies and regulations, disciplinary investigations and announcements, board meeting minutes, and internal memos/investigations, from the 1980:s and forward. Most of these documents are public, but some of them are classified. The latter especially 
applies for all minutes of the meetings (including attached reports and background information) of the Association board and all material from internal investigations by SwedSec. This material is received through personal visits at the premises of the Association and at their archives. All in all, these documents were studied to find descriptions of problems and solutions proposed in conjunction with the initiation, creation and implementation of the licensing programme. Acts and ordinances, public investigations, opinions circulated for comment, and other documents produced within the framework of the legislative process surrounding financial product marketing, sales, and consulting during the same time period have been used as background material. The same applies to reports, investigations, sanction decisions, and legal cases from supervisory authorities and judicial authorities. The material has been supplemented with official statistics on the finance and securities markets, as well as press releases and media coverage of relevance for the licensing program (collected through databases covering the most important daily newspapers and financial press of the country). In addition, some interviews were conducted with representatives of the programme in order to follow up on the problem descriptions and proposed solutions identified in the documents. ${ }^{2}$ When a quotation in this article is not followed by a reference citation, it relates to these interviews.

All in all, the empirical material and research questions constitute a case study with internal comparison centered around the fact that the program was launched but failed to get support in the beginning of the $90 \mathrm{~s}$, and then was re-launched and successful in the late 90 s and forward. Since it is the question of a single case that is studied over time in order to specify whether and how certain conditions change over time, you can also refer to the study as a longitudinal case study, where the presentation mainly takes place in chronological order to emphasize the changes over time which answers the research questions [14].

\section{Employee licensing in the Swedish securities industry: an analysis of a self-regulation project}

\section{Introduction}

The licensing scheme for employees in the Swedish securities industry that went into effect in April 2001 was initiated in October 1998 by two Association board members ([29, 31, 32, 63, 71-73]; see also [18, 30]). Both revealed they had come to speak about a license for brokers at a lunch meeting and decided to raise the issue at the next board meeting. The proposal was launched in an informative and seemingly unplanned way during a board meeting break, and garnered almost overwhelming support. One of the initiative-takers even described the reaction as a powerful "cheer of approval" ([30]: 23), and it was quickly decided to commission him to author a memo about the

\footnotetext{
$\overline{2}$ Semi-structured interviews were conducted with six persons who have had board assignments or senior positions as board chair/company MD/director of the Association/SwedSec. Interviews were conducted during personal meetings and on-site on the premises of the Association, or by phone/email. The interviews were generally followed up with fairly simple follow-up questions or personal contact to view documents or statistical information. All interview excerpts in this article are the author's own translations from the original Swedish.
} 
preconditions of a licensing programme in the Swedish securities industry [31]. The memo, presented to the Association Board in February 1999, received unanimous approval and established the direction from that point on [32].

The strong support for licensing surprised the originators of the proposal, as an almost identical proposal had been tabled at the beginning of the 1990s and had divided the Association [33, 34]. In the following sections I will try to explain why the outcomes of the two proposals to establish a licensing programme turned out so differently, by relating the proposals to the transformation of the Swedish securities industry that has taken place in recent decades. I will focus on situations that I believe were particularly relevant to the proposals that divided the Association at the beginning of the 1990s, but were well received and implemented at the end of the 1990s; I will deepen the discussion with respect to the design of the implemented programme in a concluding section.

\section{The transformation of the Swedish securities industry in the $1980 \mathrm{~s}$ and a proposal for licensing that did not receive support}

The Swedish securities industry has been centred, for most of its history, on the Stockholm Exchange and its premises on the Stortorget square in Stockholm's Gamla Stan district [35-37]. The market was relatively small, low profiled, and stable, particularly in the decades after the Second World War. In the 1950s, 1960s, and 1970s, the Exchange had essentially the same twenty banks and brokerages as Exchange members, and the number of brokers stayed at around 70-80 [38]. Brokers and Exchange employees mixed daily on the trading floor and were in a highly concrete way dependent on each other to carry out transactions for their clients. The trading floor was a logical point of contact: It was there that the informal rules were created that maintained order in how transactions should be executed and that the foundation was laid for the predictability that makes market transactions possible $([39,40]$; see also $[26,41])$.

At the Stockholm Exchange, the informal control system that consisted of this daily interaction operated parallel to a broker-approval process regulated by law (OM [32, 33, 38, 42]: 56-60). When an exchange member wanted a broker to have access to exchange trading, the member had to apply to the Board of the Exchange to have the broker approved as an exchange official. The Association was involved in this process. The Association appointed members to the reference group for approval by the Exchange; this was the same reference group that the Exchange director used when approving exchange officials. Candidates were tested for the "exchange card" within the reference group after working as a broker on the trading floor for at least a year as an apprentice to an experienced broker. Based on the reference group's opinion, the director of the Exchange issued an exchange card as proof of authorization to be a broker at the Stockholm Exchange. The reference group consisted of experienced stockbrokers appointed by the Association and representatives of the Exchange. Under this system, individual brokers stood under the supervision of brokers as a collective, were known to the management of the Exchange, and were easy to identify.

The reregulation and growth of the securities industry in the 1980s had extensive consequences, however, for the stability of the market, which had been stable for decades ([43]; OM [38, 44]). The number of exchange officials doubled and the 
number of brokerages affiliated with the Exchange became twice that of the affiliated banks (OM [38]). While the number of banks and their exchange officials increased only marginally from 1980 to 1989 (from 10 to 12 and from 60 to 69, respectively), the increase in the number of brokerages and their exchange officials was sharp: from 6 to 7 and from 31 to 85 , respectively. As the number of transactions and brokers rapidly grew, banks and brokerages soon began to find the formal control system and approval process of the Exchange too demanding. After pressure, the Exchange agreed to change the process by which exchange brokers became authorized. The formal requirements for exchange brokers remained in place, but the brokers now received eligibility from the Exchange automatically via registration by the member companies. This change also meant that the Association's role in supervision was gradually weakened. The Association went from carefully reviewing the selection of personnel, to contenting itself with maintaining lists of representatives, to entirely relinquishing that task at the beginning of the 1990s ([18]: 14; [31, 33]). In practice, therefore, there was no longer any testing of new brokers by the Exchange, so neither the Association nor its competitors had any insight into or control over what took place in individual brokerages. This happened at the same time as the daily personal contact that occurred via business transactions, and that had so far been taken for granted, declined drastically. Parallel to the increasing number of exchange officials, the Exchange's highly traditional premises had begun to seem increasingly crowded. The Exchange therefore initiated an effort to find more spacious premises, which led to its abandonment of the traditional trading floor in the Exchange building in spring and summer 1990 ([45]: 18-21, [46, 47]). The Stockholm Exchange was among the first financial exchanges to abolish floor trading, which was replaced with an electronic trading system whereby exchange trading was executed in the office premises of the various member companies, with telephones and computers connected to the Exchange. The transition to electronic trading was in turn a key step in the progress toward ever more and increasingly complicated transactions being executed by an increasing number of actors.

Changes of the type described above often lead to uncertainty as they drastically reduce traders' ability to "know [their] fellow traders, who to trust, how to impose informal sanctions that work effectively, or even to identify what other traders are doing around you" ([26]: 311). This was also the case in the Swedish securities market. The fact that transactions were now executed remotely and by an increasing proportion of actors who were unknown to each other created regret among the members for the mutual trust that had existed. These changes led to a lengthy, lively discussion about tightening the rules and routines for exchange officials, and proposals were tabled to introduce a certification of exchange, institutional, and option brokers based on competence monitoring ([33]s: Art. 13, b: Art. 14; [30]: 20-22, [18]). The proposal was discussed in detail by the Board of the Association, which also took a position regarding a memo written by one of the Board members. The memo pointed out that certification could serve as a steering instrument in that brokers who behaved badly risked losing their certification and being barred from acting as brokers. It was considered that competence and suitability would be documented and "that unsuitable persons would not be permitted to return to the broker role with a new employer" (SFF 1990b, Appendix 1, p. 3). Any certification could serve as a guarantee that the brokers have sufficient expertise to perform their duties and thus also as a guarantee of fewer 
cases of inappropriate handling and errors. In the longer term, such a system would raise brokers' status and self-esteem and increase public confidence in brokers generally and in the securities industry more broadly. It is noteworthy that the question of lack of confidence was directed internally within the industry and specifically towards employers. Less scrupulous employers were held responsible as they, through their actions in employee selection and hiring, sent the wrong signals to clients and colleagues in the industry:

Experience shows that certain employers make greater demands than do others as regards the selection and hiring of brokers. It has happened that brokers who have overstepped their authority who have otherwise behaved inappropriately at a workplace reappear after some time in the role of broker with a new employer. This sends less-confidence-inspiring "signals" to both the broker's previous clients and to broker colleagues in interbank trading. (SFF 1990b, Appendix 1, p. 2)

The criticism of "certain employers" was also expressed in a recommendation for greater vigilance in the recruitment and filling of broker positions in member companies (SFF 1990b). The Association, however, was split on these issues and the proposal received weak support. The confidence issue and the difficulty in achieving consensus coincided with the financial crisis into which the sector was drawn at the time of the proposal. The expansion of the markets was interrupted by the extremely severe banking crisis in the Swedish finance sector during the transition to the 1990s and the years immediately following [37, 43]. In 1990, the number of transactions on the Stockholm Exchange declined sharply, as did the net sales and value of the Exchange (OM $[38,47,48])$. Several industry actors were forced to withdraw from the market or reduce their operations. The number of formally approved Exchange members declined, and personnel reductions threatened to become the most dramatic in the history of the industry. Competition for job opportunities in the sector became intense, the room for profit per transaction became relatively low, and cooperation projects like the certification proposal could not be realized (SFF 1990b: Art. 4; [44, 47, 48]).

Overall, two intertwined conditions seem to have been the basis as to why the selfregulatory initiative raised in the beginning of the early 90 s not received support and failed almost immediately: Firstly, the lack of confidence between market actors and internal industry criticism of member companies and "certain employers", secondly the financial crisis, stagnant growth and heated market competition in the industry.

\section{The transformation of the Swedish securities market in the 1990s and the implemented licensing programme as identity assurance}

After a few years with stagnant growth in the early 1990s, a period of securities market growth and restructuring ensued that was dramatic in all respects, particularly from the mid-1990s on. In addition to the previous changes - i.e., the close social contacts of the trading floor giving way to electronic trading and the growth in brokerage firms that made them undeniably greater in number and in number of officials than the banks more changes could now be added. These changes, which became well known to broad 
sectors of the population, included a sharply increased percentage of foreign actors (an entirely new element), the dissolution of the Exchange's monopoly and the growth of alternative marketplaces, an industry shift whereby previously distinct banking, finance, and insurance operations tended to meld together, and the dissemination of exchange information to external actors [38, 43, 44, 49]. The differences between the types of actors embodying the changes enabled by the reregulation of political restrictions on financial operations of the 1980s, and by the restructurings during the "bubble years" from the mid-1990s on, are particularly noteworthy ([39, 43]: 205-215; [49]). In the first case, it was primarily a matter of actors in the securities industry and other industries. In the second case, it was instead a matter of a significant broadening of the market: the large numbers of buyers and sellers without prior experience or fall-back contact networks who came to populate the securities markets; new hirings of young, inexperienced people by banks and brokerages; daytraders for whom securities trading was something between a regular professional activity and a hobby; and clients from broader sectors of the population who had started investing in the market by buying shares and advanced securities for their savings ([7]: 35; [50]: 286; [44, 49, 51]: 40f., Ch. 13).

Common to the changes described above was that they entailed the establishment of an increasing number of contact interfaces, exceeding the capacity of earlier personal acquaintance networks and informal social control. An earlier relatively small and stable market, characterized by dense networks in which most people knew each other, was broken up in a short time and integrated with international influences and persons from broad sectors of society, with varying abilities and circumstances. This powerful and rapid expansion made the market heterogeneous and difficult to grasp as a whole, and the misunderstandings were many. The problems manifested themselves in assignments and hiring that led to complaints and disputes between market actors, as well as subsequent legal cases involving not only large banks and well-known brokerages but also individual daytraders [7, 52-62].

Unlike the internal industry criticism of member companies and "certain employers" that had been prominent in the early 1990s, the focus was now on the brokers and their competence. Companies in the industry described difficulties in finding competent people at a time of service production requiring increasing expertise, and feared strong international competition for well-educated candidates. The level of knowledge among the brokers "on the floor" was perceived to be too low and uneven, and the quality of their action unsatisfactory. The need for quality control, quality standards, and quality assurance strongly marked the discussion of the brokers' actions in the securities market, and standards for how transactions should be executed and complexity reduced were perceived as increasingly desirable ([44, 63]: 378).

Personal networks and trust-based relationships, of course, continued to be important to reaching agreement, upholding the rules of play and practical guidelines, and executing transactions, but were no longer sufficient. Accordingly, there was greater demand for and acceptance of standardized systems and "impersonal trust" $[64,65] .^{3}$

\footnotetext{
3 The concept "impersonal trust" refers to a type of social relationship where transactions between people are mediated by (or "embedded in") a formal social organization rather than in personal social relations. Instead of trust based on some kind of personal knowledge or recommendations actors are acting on the basis of the trust that emanate from the investments in institutional anchored resources, as a graduate, a professional title or a license. See [64-66] for a discussion.
} 
The regulations and knowledge test of the licensing programme were given a standardized form and the trust that was engendered by the license was therefore primarily impersonal trust. In an expansive, dynamic world of inclusive, expanding ambitions, the knowledge test is also an attractive instrument with which to strengthen the market's symbolic functions, as it is potentially universalistic in character and relatively easy to individualize and standardize. At the same time, a license signals dependability and productive capacity, clears away suspicion and uncertainty, and makes it easier for investors to determine which brokers are worth engaging or hiring: it is a type of quality guarantee or quality assurance to prevent major recruitment mistakes.

The period's focus on quality indicated both an orientation problem and a need for support and standards to ensure that lucrative business opportunities could be exploited and resource-consuming difficulties (i.e., misunderstandings, disputes, and complaints) avoided. The license was also formulated to support employers, but without representatives of any employee organization being involved (see further details in the following section), and was intended from the start to serve as a selection instrument for new recruitment. The idea was that a license could serve as a guarantee of quality to ensure correct personnel selection, because, as one of the initiators put it, "there were a few examples of hiring failures in which there was nothing to indicate poor selection from the start, but that eventually turned out to be seriously wrong" (see also [63]: Art. 1). In addition, the Association asserted that licensing would "put the focus on the responsibility of the individual, which could relieve the burden of any sanctions on the employer in connection with criminal offenses" and that the license would "deter actions by industry employees that could damage employer companies" ([63], Appendix 1, p. 4).

Since it is reasonable to initially construe the licensing programme's relatively rigorous and internally focused control mechanisms as an expression of suspicion and a way to limit access to the securities market, the programme's voluntary and inclusive character should be emphasized: affiliation is voluntary, the opportunity to obtain a license is open to all, and the representatives have insisted that their intention is that the license should "bring in as many as possible". The Association has also consistently promoted expansion of the licensing programme and has set its requirements at a relatively basic level. The license is designed, as stated above, to ensure a basic competence - a "guarantee of quality", as the representatives put it ([67]; cf. [63]). During the implementation of the licensing programme, special attention was paid to achieving a precise definition of the programme's own operations, thereby highlighting its distinctive nature. Rule systems and knowledge tests essentially concern professional knowledge of how the current market and financial instruments work and how trading in these instruments should take place, how trading should be administered, and how the associated risk should be assessed. Since the programme's control function does not significantly change access to the market, but does compel market actors to declare who they are - which facilitates the identification of market actors, market transactions, and "correct selection" - I contend that the programme's fundamental control function should be understood in terms of identity assurance. With rule systems and knowledge requirements come a common signal system that helps define the market and binds together industry actors in a clear consensus as to how the market works and how trades should be executed, which strengthens the market actors' freedom of action and enables ongoing expansion of the securities market. 
The openness and inclusiveness that characterizes identity assurance, in comparison with access control, can be associated with the confidence that characterized the market at this time. In stark contrast to the crisis years in the early 1990s, the second half of the 1990s was characterized by growth and confidence never seen before. Job opportunities, earnings, and market expansion were extremely lucrative, particularly as a result of the rapid normalization of stock market investing, and rose sharply in the Swedish population [7, 44, 49, 68]. The change in the number of brokers and traders and in exchange trading volume was dramatic. In 1990 there were 174 exchange brokers executing slightly over 2000 trades per day. In 1998 there were over three times more (585) brokers, executing over ten times more trades per day [38]. During the same period, the value of stock trades rose from a few hundred million SEK to seven billion SEK per day. Total revenue for the securities industry rose sharply starting in the mid-1990s, and the industry's self-confidence was extremely strong [69]. During this period, however, the companies were intensely preoccupied with their own expansion and growth, and displayed little interest in devoting time, energy, and resources to administrative measures designed to improve quality in companies' internal operations [52, 53, 58-62]. The foundation for affiliation with industry-wide projects was therefore solid.

Overall, three intertwined conditions seem to have been the basis for the selfregulatory initiative launched at the end of the 90s received immediate and strong support: growth and confidence; a significant broadening of the market with spreading and heterogenity of market actors; quality problems and criticism directed against brokers and their competence; three conditions that differ dramatically from the situation in the early 90 s.

\section{Identity assurance and integrity markers: digression about the licensing programme implementation}

Growth and confidence, expansion and heterogeneity, quality problems, and criticism of brokers were characteristic aspects of the Swedish securities market at the end of the 1990s, compared with the situation at the beginning of the 1990s, and can be seen in relation to the spread of the licensing programme. The programme was designed in the innermost circle of the Association, without publicity and without intervention from external parties, and was characterized by a large measure of integrity [70]. The initiators within the Association were intent on designing the project themselves so as to "give it their own imprint", as one of them described it, and put special effort into defining and designing the distinctive nature of the programme's operations. The fundamental components of the programme were "unquestioned right from the first moment and not open to debate". The Association itself took on the labour and expenses required for the project, which was organized by a small team of just a few people. The team won support for the project from influential directors of prominent securities companies and followed up on that by gaining support from the managements of the country's large banks, which - being personnel intensive - would be significantly affected by the programme. The strategy was perceived as extremely important for the success of the work, as formulated by one of the initiators of the programme (see also [32], Appendix 1): 
The way it worked was that early on we ... secured the support of the top management of some of the banks. Once we had some of the banks' managing directors on board, we felt confident enough to proceed, assuming that the rest of the banks would not dare to go against the tide, which proved correct. I don't believe we would have had such success with the banks if we had approached them lower down in their organizations, since hesitation about costly projects can be greater there.

It was not until the proposal was established and fully supported by its members that the Association turned to the world outside, but then more or less exclusively to provide information about the project. The unwillingness to allow other actors to participate in designing the programme was consistent and clearly indicated, particularly in relation to the industry's trade union, i.e., the Financial Sector Union (FSU; Finansförbundet), the regulatory authority, i.e., the Financial Supervisory Authority, and the Ministry of Finance. These bodies were, in the words of one of the leading initiators of the project, "obviously not conceivable co-partners". Although its members would be significantly affected by the project, the FSU was not involved at all, though it did express support for the project once it was informed of it. However, the Association was reluctant, as they put it, due to "less-than-positive experiences" of earlier cooperation with the FSU, which they "wanted to avoid" repeating.

Nor was the Authority informed of the plans before the Association considered itself obliged to do so, a situation that occurred earlier than the Association had hoped. The Association announced the project publicly in spring 1999 when the Authority - as a result of several widely publicized cases of serious criminality and improper practice by brokers in the industry - confronted the Association and the other organizations in the bank and finance industry with an extremely critical "action plan" ([52, 63]: Art. 16, c: Art. 5, d: Art. 1, e: Art. 8). In the action plan, the Authority described the incidents that in its view indicated "a general weakening of the culture in the sector", and presented a long list of conceivable measures to create greater compliance with the rules ([7, 52, 53]: 35). Within the Association, there was a highly negative reaction to the Authority's descriptions and action plans ([71], Appendix 1, p. 2). On one point, however, the Authority's suggestions were aligned with the Association's aims. The action plan contained several suggests for training, among them that personnel with client contacts should undergo a knowledge test ([52]: 2; [63]). This, of course, was an opportunity for the Association to welcome the Authority's proposal, perhaps even propose cooperation in the area, or even leave it to the Authority to advocate for the proposal. Within the Association it was already understood that the project could end up being both expensive and laborious to implement. For an industry representative to propose to its members a costly self-regulation initiative also entails a risk of protest and discontent, particularly when the proposal implies that thousands of industry employees would not be allowed to continue in their jobs unless they successfully passed an extensive knowledge test.

However, the Association elected not even to comment on the Authority's proposal in its response to the action plan ([71]: Art. 1, Appendix 1). Instead, the Association presented its own project, describing it as "extremely extensive and utterly significant", and made it clear that the Authority would be informed of its development ([71], Appendix 2). In addition, the Association put significant effort into criticizing the other 
suggestions in the action plan and expressed strong doubt that the Authority had the necessary capacity to maintain competent, trust-inspiring, and fair regulatory operations ([71], Appendix 1). The Association had no interest in any cooperation - an attitude that the initiators of the programme commented on as follows:

Frankly speaking, we were convinced that we could do things so much better and doubted the Inspectorate's [i.e., Financial Supervisory Authority's] ability. Naturally, we knew that the Inspectorate, with the support of the law, could take over at any time and can still do so, but we focused on doing our job so that it would be done well and, if so, would ensure that the foundation we had built would be used. We also knew that by doing it well we would be taking such a strong initiative that we would be able to keep [control over] it.

The Association's remarks vis-à-vis the Authority's problem descriptions, action plans, and ability to exercise competent, efficient supervision were recurrent and strong during the period in which the licensing programme was initiated and implemented. ${ }^{4}$ The Association's criticism of the Authority was expressed in parallel to their emphasizing their own capacity in the area and placing great importance on designing and advocating a system aligned with the important international securities markets, particularly in the UK and in the USA [73]. Finally, it should be pointed out that a selfregulatory programme based on a knowledge test indicates maturity, identity, and integrity, in that an actor who is associated with and invokes specialized knowledge can present his actions as relatively neutral and independent of special interests. Such a programme is attractive for an industry whose actors must function at a time when the boundary between professional practitioners and clients is tending to dissolve and practitioners are often accused of acting out of speculative self-interest $[19,74]-\mathrm{a}$ development that became increasingly prominent in the Swedish securities industry with the sharp stock market downturn at the beginning of the 2000s and was thus associated with trust problems $[44,75]$. At this point, the licensing programme was already well supported by the industry and could also be trust-enhancing more generally. This circumstance, however, should not obscure our view of the more fundamental orientation problems caused by the changes in the finance and securities industry and that the demand for quality - and its specific manifestation in standardized knowledge tests and licensing - should, to my understanding, be seen as expressing.

\section{Concluding remarks}

During recent years the ambition to constitute markets and promote market transactions has led to a dramatical increase of regulations and regulatory agencies in the global capitalistic economy, a change described as" regulatory capitalism" $[1-3,5]$.

\footnotetext{
${ }^{4}$ In this context, it should be pointed out that the Association's representatives have stressed that the Financial Supervisory Authority eventually became "perhaps our strongest supporter". However, this is considered not to have occurred before "we had got under way" and the Authority "realised the importance of what we did"; see also FI [7, 53], Jansson [18, 30], and SFF [72].
} 
Governments as well as private actors have spent resources and prestige in regulatory projects where an increased scope for professional actors and experts to shape and uphold the regulations has been a significant element. One example is self-regulation in the shape of licensing of employees, which has been introduced in an increasing number of finance and securities markets. The Swedish Securities Dealers' Association's ("the Association") project of sublicensing employees was one of the first examples of this. In this article the emergence of this program has been studied, from the first and failed initiation in the beginning of the $90 \mathrm{~s}$, to the second and successful initiation and implementation of the program in the late $90 \mathrm{~s}$ and forward.

Two lessons can be drawn from the analysis. The first lesson is centered around what characterizes self-regulation. The program in question consists of several components; knowledge requirements and knowledge tests, a sanction system and a reporting duty, a network-based organizational structure and voluntary membership are the most prominent. In this article I have argued that these components constitute a form of selfregulation whose fundamental characteristic is best understood as identity assurance; a form of control the primary focus of which is that an actor must declare his or her identity and so centered around transparency. The conceptualization of identity assurance is of value given that self-regulation is often understood in terms of access control, centered around defending one's own interest, building barriers and thereby exclude others from the market.

This leads us to a second lesson. Self-regulation is all too often understood only as a strategy to avert criticism against the (finance and securities) industry in times of financial crisis and legitimation problems. In contrast, I have set out the growth of self-regulation as identity assurance in a market characterized by growth and confidence, spreading and heterogeneity, quality problems and criticism of brokers. In this context, the licensing programme could be linked with industry actors in a clearer consensus as how business transactions should be implemented, identification and selection of business facilitated, and lucrative business opportunities therefore exploited. The programme was so well suited to facilitate market transactions in that more people could be included in the circle of competent market actors. In this way, the study contributes to understanding of which situations induce private actors to invest in self-regulation, how the underlying market problems constitute the type of self-regulation, as well as our understanding of the proliferation of contemporary regulatory capitalism and financialization $[1,5,9]$. In addition to the fact that this study teaches us how self-regulation can be initiated in an expanding economy full of expectation, it also gives us hypotheses for future research on which underlying challenges of the market which pushes forward and constitute what form of self-regulation.

Besides the above, what next? I will give one example. From the study it is presumably highly significant not only which actor takes initiatives, and how support for these initiatives is achieved by different actors inside and outside the industry. The present study comprises examples of how actors can endeavour to invite, neglect, or actively distance themselves from other actors, a fact that seems to be a case of "statussignalling" [76]. When market actors choose between multiple cooperation partners they signal status, and difficulties identifying quality involve uncertainty that causes actors to seek out actors of analogous status to themselves - a process which constitutes the conditions that adopting self-regulation to assume an inclusion (e.g. identity assurance) or exclusionary character (e.g. access control). This would be a productive 
avenue to pursue in the future, in order to develop our understanding of the form and conditions involved in self-regulation. How actors initiate, support, or counteract initiatives - or even are unaware of what is going on - and how these relationships constitute the self of self-regulation - and thus what type of self-regulation it is possible to comprehend - is an area where much is left to do.

Acknowledgments This work was supported by the Swedish Research Council (Vetenskapsrådet), grant no. 2007-2179, "Crime Prevention in the Financial Markets".

Open Access This article is distributed under the terms of the Creative Commons Attribution 4.0 International License (http://creativecommons.org/licenses/by/4.0/), which permits unrestricted use, distribution, and reproduction in any medium, provided you give appropriate credit to the original author(s) and the source, provide a link to the Creative Commons license, and indicate if changes were made.

\section{References}

1. Braithwaite, J. (2008). Regulatory capitalism. How it works, ideas for making it work better. Cheltenham: Edward Elgar.

2. Levi-Faur, D. (2005). The global diffusion of regulatory capitalism. The Annals of the American Academy of Political and Social Science, 598(1), 12-32.

3. Levi-Faur, D. (2017). Regulatory capitalism. In P. Drahos (Ed.), Regulatory theory. Foundations and applications. Canberra: ANU Press.

4. Parker, C., \& Nielsen, V. (2009). The challenge of empirical research on business compliance in regulatory capitalism. Annual Review of Law and Social Sciences, 5(December), 45-70.

5. Levi-Faur, D. (2011). Regulation and regulatory governance. In D. Levi-Faur (Ed.), Handbook on the politics of regulation. Cheltenham: Edward Elgar.

6. Lütz, S., Eberle, D., \& Lauter, D. (2011). Varieties of private self-regulation in European capitalism: corporate governance codes in the UK and Germany. Socio-Economic Review, 9(2), 315-338.

7. FI. (2001a). Aktiemarknad för alla - nya krav i ny miljö. Stockholm: Finansinspektionen.

8. Belfrage, C. (2008). Towards 'universal financialisation' in Sweden? Contemporary Politics, 14(3), 277296.

9. Van der Zwan, N. (2014). Making sense of financialization. Socio-Economic Review, 12(1), 99-129.

10. Short, J. L., \& Toffel, M. W. (2010). Making self-regulation more than merely symbolic: The critical role of legal environment. Administrative Science Quarterly, 55(3), 361-396.

11. Mayntz, R. (2012). Instituitional change in the regulation of financial markets: Questions and answers. In R. Mayntz (Ed.), Crisis and control. Institutional change in financial market regulation. Frankfurt: Campus Verlag.

12. Ogus, A., \& Carbonara, E. (2012). Self-regulation. In F. Parisi (Ed.), Production of legal rules. Cheltenham: Edward Elgar.

13. Philipsen, N. (2011). Professional licensing and self-regulation in Europe and China: A law and economics perspective. In M. Faure \& X. Zhang (Eds.), Competition policy and regulation. Recent developments in China, the US and Europe. Cheltenham: Edward Elgar.

14. Yin, R. K. (2013). Case study research. Design and methods. Fifth edition. London: Sage.

15. Jordana, J., \& Levi-Faur, D. (Eds.). (2004). The politics of regulation: Institutions and regulatory reforms for the age of governance. Northampton: Edward Elgar Publishing.

16. Jordana, J., \& Levi-Faur, D. (2010). Exploring trends and variations in agency scope. Competition and Regulation in Network Industries, 11(4), 342-360.

17. Engdahl, O., \& Larsson, B. (2015). Duties to distrust: The decentring of economic and white-collar crime policing in Sweden. British Journal of Criminology, 56(3), 515-536.

18. Jansson, P.-O. (2008). Svenska fondhandlareföreningen etthundra år: 1908-2008. Stockholm: Svenska fondhandlareföreningen.

19. Preda, A. (2009). Framing finance: The boundaries of markets and modern capitalism. Chicago: University of Chicago Press. 
20. Yue, L. Q., Luo, J., \& Ingram, P. (2013). The failure of private regulation: elite control and market crises in the Manhattan banking industry. Administrative Science Quarterly, 58(1), 137-169.

21. Ayres, I., \& Braithwaite, J. (1992). Responsive regulation. Transcending the deregulation debate. New York: Oxford University Press.

22. Baldwin, R., Cave, M., \& Lodge, M. (2011). Understanding regulation. Theory, strategy, and practice. Second edition. Oxford: Oxford University Press.

23. Baggott, R., \& Harrison, L. (1986). The politics of self-regulation: the case of advertising control. Policy \& Politics, 14(2), 143-159.

24. Clarke, M. (2000). Regulation. The social control of business between law and politics. Basingstoke: Palgrave MacMillan.

25. Weingast, B. (1980). Physicians, DNA research scientists, and the market for lemons. In R. D. Blair \& R. Stephen (Eds.), Regulating the professions: A public-policy symposion. Lexington: Lexington Books.

26. Gunningham, N. (1991). Private ordering, self-regulation and futures markets: a comparative study of informal social control. Law \& Policy, 13(4), 297-326.

27. SwedSec. (2016). SwedSec's rules and regulations with commentaries 1 January 2016. Stockholm: SwedSec.

28. SwedSec. (2014). SwedSecs vägledning för anmälan av regelöverträdelser. Stockholm: SwedSec.

29. SFF (1999f). Protokoll fört vid sammanträde med Svenska Fondhandlareföreningens styrelse den 21 oktober 1999

30. Jansson, P.-O. (2011). Att vara på den säkra sidan. Tio år med SwedSec i värdepappersmarknaden-En jubileumsskrift. Stockholm: SwedSec.

31. SFF (1998). Protokoll fört vid sammanträde med Svenska Fondhandlareföreningens styrelse den 22 oktober 1998.

32. SFF (1999a). Protokoll fört vid sammanträde med Svenska Fondhandlareföreningens styrelse den 11 februari 1999.

33. SFF (1990b). Protokoll fört vid sammanträde med Svenska Fondhandlareföreningens styrelse den 31 maj 1990.

34. SFF (Svenska fondhandlareföreningen) (1990a). Protokoll fört vid sammanträde med Svenska Fondhandlareföreningens styrelse den 18 januari 1990.

35. Algott, S. (1963). Stockholms Fondbörs 100 år. Stockholm: Nord. Bokh.

36. Hägg, I. (Ed.). (1988). Stockholms Fondbörs - riskkapitalmarknad i omvandling. Stockholm: SNS Förlag.

37. Niemeyer, J. (2000). Värdepappershandel i Sverige. In SOU (Ed.), Finanssektorns framtid. Betänkande av Finansmarknadsutredningen. Stockholm: Fritzes.

38. OM Stockholm Exchange. (1999). Fact book 1999/Stockholm stock exchange. Stockholm: OM Stockholm Exchange.

39. Hallvarsson, M. (1988). 1970-talet - en förberedelseperiod för 1980-talets omvälvning. In I. Hägg (Ed.), Stockholms Fondbörs - riskkapitalmarknad i omvandling. SNS Förlag: Stockholm.

40. Isaksson, A. (1988). Livet på börsgolvet. In I. Hägg (Ed.), Stockholms Fondbörs - riskkapitalmarknad $i$ omvandling. SNS Förlag: Stockholm.

41. Abolafia, M. Y. (1996). Making markets. Opportunism and restraint on Wall Street. Cambridge: Harvard University Press.

42. SOU (Statens Offentliga Utredningar). (1973). Fondbörsen. Betänkande av Fondbörsutredningen. Stockholm: Liber.

43. Larsson, M. (1998). Staten och kapitalet. Det svenska finansiella systemet under 1900-talet. Stockholm: SNS Förlag.

44. SOU (Statens Offentliga Utredningar). (2000). Finanssektorns framtid. Betänkande av Finansmarknadsutredningen. Stockholm: Fritzes.

45. Stockholms Fondbörs. (1989). Årsrapport 1988. Stockholm: Fondbörsen.

46. Stockholms Fondbörs. (1990). Årsrapport 1989. Stockholm: Fondbörsen.

47. Stockholms Fondbörs. (1991). Årsrapport 1990. Stockholm: Fondbörsen.

48. Stockholms Fondbörs. (1992). Årsrapport 1991. Stockholm: Fondbörsen.

49. Nilsson, F. (2003). Aktiesparandets förlovade land. Människors möte med aktiemarknaden. Stockholm: Brutus Östlings Bokförlag Symposion.

50. Hallvarsson \& Halvarsson. (2004). Intressekonflikter hos fondkommissionärer. In SOU (Ed.), Näringslivet och förtroendet. Betänkande av Förtroendekommissionen. Stockholm: Fritzes.

51. Jungerhem, S. (2000). Arbetskraft och konkurrenskraft i den svenska finansiella sektorn. In J. Niemeyer \& H. Bäckström (Eds.), Finanssektorns framtid - bilagor till finansmarknadsutredningen. Betänkande av Finansmarknadsutredningen. Stockholm: Fritzes. 
52. FI (Finansinspektionen). (1999a). 'Aktionsplan' för att stärka marknadens förtroende. Utkast 1999-0324. Stockholm: Finansinspektionen.

53. FI. (1999b). Aktionsplan för att stärka förtroendet för värdepappersmarknaden. Stockholm: Finansinspektionen.

54. FI. (1999c). Översyn av insiderlagstiftningen. Stockholm: Finansinspektionen \& Ekobrottsmyndigheten.

55. FI. (1999d). Undersökningar om Nordbanken AB (publ.). Stockholm: Finansinspektionen.

56. FI. (1999e). Undersökning av Matteus Fondkommission AB. Stockholm: Finansinspektionen.

57. FI. (2001b). Fondbolagens information och interna kontroll. Stockholm: Finansinspektionen.

58. SDC (Stockholm District Court) (2000). Decision of Stockholm District Court 2000-09-28 in Case B 7874-99.

59. SDC (Stockholm District Court) (2001). Decision of Stockholm District Court 2001-01-25 in Case B 1432-99.

60. SDC (Stockholm District Court) (2002). Decision of Stockholm District Court 2002-01-10 in Case B 700-99.

61. SDC (Stockholm District Court) (2003). Decision of Stockholm District Court 2003-11-19 in Case B 5222-01.

62. SDC (Stockholm District Court) (2004). Decision of Stockholm District Court 2004-09-16 in Case B 2357-00

63. SFF (1999b). Protokoll fört vid sammanträde med Svenska Fondhandlareföreningens styrelse den 25 mars 1999.

64. Pixley, J. (1999). Impersonal trust in global mediating organizations. Sociological Perspectives, 42(4), $647-671$.

65. Shapiro, S. P. (1987). The social control of impersonal trust. American Journal of Sociology, 93(3), 623658.

66. Larsson, B. (2007). Unpacking professional trust - dimensions of trust in Swedish auditors' client relations. Sociological Research Online, 12(2). https://doi.org/10.5153/sro.1531.

67. SFF. (2000). Yttrande: Slutbetänkande av konsumentpolitiska kommittén 2000 (SOU 2000:29). Stockholm: Svenska fondhandlareföreningen.

68. Scb (Statistiska Centralbyrån). (2013). Sparbarometern: Hushållens ställning 1980-2013kv3. Stockholm: $\mathrm{ScB}$.

69. Thomasson, A. (2001). Handel med värdepapper - en uthållig tillväxtbransch. Aktiespararen, 35, 6-9.

70. Parsons, T., \& Platt, G. M. (1973). The American University. Cambridge: Harvard University Press.

71. SFF (1999d). Protokoll fört vid sammanträde med Svenska Fondhandlareföreningens styrelse den 7 maj 1999.

72. SFF (1999e). Protokoll fört vid sammanträde med Svenska Fondhandlareföreningens styrelse den 27 maj 1999.

73. SFF (1999c). Protokoll fört vid sammanträde med Svenska Fondhandlareföreningens styrelse den 22 april 1999.

74. de Goede, M. (2005). Virtue, fortune, and faith. A genealogy of finance. Minneapolis: Minnesota University Press.

75. SOU (Statens Offentliga Utredningar). (2004). Näringslivet och förtroendet. Betänkande av Förtroendekommissionen. Stockholm: Fritzes.

76. Podolny, J. M. (2010). Status-signals. A sociological study of market competition. Princeton: Princeton University Press. 